\title{
ЖИТТЕВІ ПЕРСПЕКТИВИ ОСОБИСТОСТІ, ЩО ЗНАХОДИТЬСЯ В УМОВАХ АТО (АНТИ-ТЕРОРИСТИЧНОЇ ОПЕРАЦІї)
}

УДК: 159.923:341.321

\section{Павленко Оксана Володимирівна}

Науковий співробітник лабораторії екологічної психології Інституту психології імені Г. С. Костюка Національної академії педагогічних наук Украӥни, м. Київ (Украӥна)

ORCID ID: https://orcid.org/0000-0002-1263-4989

\begin{abstract}
Анотація. У статті розглянуто особливості формування життєвої перспективи особистістю, щу знаходиться в умовах АТО. Розкрито основні параметри, функцї та форми усвідомлення власних життєвих перспектив особистістю. Виділені наступні характеристики та компоненти життєвої перспективи особистості: диференційованість/не диференційованість змістовний компонент, оптимістичність/песимістичність - емоційно-переживальний компонент, реалістичність/нереалістичність - прагматично-практичний компонент, нормативність/ особистісність - смисловий компонент. Згідно із изими компонентами зроблено аналіз структури життєвої перспективи респондентів, щзо перебувають у зоні АТО, зокрема бійців АТО, внутрішньо переміщених осіб, мешканців «сірих» зон та мешканців стабільних територій Украӥни. Виявлено та проаналізовано розбіжності у представлені перспективи власного життя у свідомості ицих груп респондентів. Виявлено, щчо найменш диференційована перспектива для представників групи військові АТО. Оптимістичність що до власного майбутнього продемонстрували всі категорії респондентів. Осмисленість власної перспективи знаходиться на досить високому рівні для всіх груп респондентів, пов 'язаних з АТО, проте події найчастіше обираються по нормативній ознаці на відміну від представників групи стабільних територій. Рефлексивність щчо до дій, які необхідно здійснити для настання тієї чи іншої плануємої чи передбаченої подї продемонстрували представники групи ВПО, за ичим показником вони перевершали представників групи стабільних регіонів. За результатами проведеного дослідження ми можемо зазначити, щэо для побудови диференційованої, оптимістичної, реалістичної та особистісної перспективи особистості необхідно врахування змісту перспективи, ї емоційної оцінки, смислової та прагматичнопрактичної складової. Результати наведеного дослідження можуть бути використані для
\end{abstract}


створення програми психологічної допомоги бійцям АТО, ВПО та мешканцям прикордонних із зоною АТО територій (сірих зон) для фасилітації побудови ними перспективи власного майбутнього.

Ключові слова: життєва перспектива особистості, характеристики життєвої перспективи, життєвий досвід, плановані подї, формування узгодженої перспективи власного життя.

Постановка проблеми дослідження. Останнім часом в нашій країні відбуваються зміни у життєдіяльності багатьох членів нашого суспільства. Кардинальні змін зазнав образ життя тих категорій населення, які безпосередньо задіяні у подіях на сході України. Перед людьми постало завдання пережити травмуючи події минулого, зробити їх власним досвідом, пристосуватися до змін, які відбулися в їхьому сьогоденні та побудувати нову життєву перспективу. При цьому треба враховувати, що сьогодення, для цих людей $\epsilon$ доволі невизначеним, що ускладнює завдання побудови перспективи власного майбутнього.

Тобто складні життєві обставини вимагають від особистості перегляду чи зміни попередніх стратегій життєдіяльності що до ставлення до власного часу життя та перспективи власного майбутнього та побудови нової узгодженої із завданнями, які ставить перед особистістю сьогодення, перспективи власного майбутнього.

\section{Аналіз останніх досліджень і публіка-} цій. На даний момент, за багатьма дослідженнями, переважаючими емоціями у населення та учасників зони озброєного конфлікту діагностовано: тривога, роздратованість, агресія, та страхи, що відображають негативну карти- ну психічного стану населення [4].

Психологічні наслідки участі у подіях, що загрожують життю чи здоров'ю особистості, можуть виявитися у посттравматичному стресовому розладі (ПТСР), що виникає як гостра, затяжна або відстрочена реакція на загрожуючи життю ситуації. [6]

Питання діагностики та реабілітації ПТСР для осіб, що брали участь у бойових діях, чи знаходились у зоні бойових дій на сьогоднішній момент $є$ доволі дослідженим (C. Хоружий, I. Пішко, Н. Лозінська, Н. Тарабіна, М. Бабенко, М. Ротань, М. Варій, Н. Титаренко та ін.) [3, 5]. С.М. Хоружим було представлено загальну характеристику парадигм психологічної допомоги особистості, що пережила травматичні стресові ситуації, пов'язані із АTO та запропонована програма індивідуальної та групової допомоги [7]. Проте питання зміни ставлення особистості до часу свого життя та прийняття власного часового континууму в наш час не $є$ достатньо дослідженим.

Життєва перспектива - реальний потенціал, можливості особистості, що базуються на минулому досвіді, є об'єктивно наявними в теперішньому і мають проявитися в майбутньому. 
Життєва перспектива організовує і направляє активність особистості в сьогоденні щодо досягнення поставлених цілей. 3 точки зору К.О. Абульхановой-Славської, здатність особистості регулювати, організовувати свій життєвий шлях як ціле, підпорядковане іiі цілям, цінностям, є вищий рівень будування оптимальної якісті суб'єкта життя. На думку Є.І. Головахи [1] життєву перспективу слід розглядати як цілісну картину майбутнього в складному та суперечливому взаємозв'язку програмованих та очікуваних подій, з якими людина пов'язує соціальну цінність та індивідуальний смисл свого життя.

Дослідники (К.Левін, Т. Коттле, Я.В. Васильєв, К. Обуховський, Є.І. Головаха, Т.Н. Березіна, Л.Д. Тодорів, Д.А. Леонтьєв, М.М. Толстих, В.С. Хомик, О.В. Шелобанова, І.О. Ральнікова, Ж. Нюттен) вказують на такі базові теоретичні підстави для осмислення поняття життєві перспективи особистості, як локалізація іiї в свідомості, зміст життєвих перспектив становить сукупність планованих і очікуваних у майбутньому подій, структура перспективи особистості являє собою сукупність стійких зав'язків між подіями, які належать до модусу майбутнього, а також до модусів минулого i сьогодення, збудована в логіці «причина - наслідок», «мета - засіб», які забезпечують эї цілісність.

При оцінці параметрів життєвої перспективи найчастіше використовують бінарні параметри: оптимістичність/песимістичність, особистісність/нормативність, реалістичність/ не реалистичність, диференційованість/не диференційованість. Важливою умовою формування життєвої перспективи, яка веде до розвитку особистості є диференційована, реалістична, позитивна та особистісна перспектива.

Основними функціями життєвої перспективи є регулятивна, прогностична, пізнавальна, транзитивна, оціночна та адаптаційна.

Формою усвідомлення особистістю власних перспектив $€$ прогнозування, проектування та програмування.

Усвідомлена та узгоджена життєва перспектива особистості визначає перехід від стихійного засобу життя до такого, який вона буде створювати власноруч. Саме тому наявність диференційованої та узгодженої перспективи є необхідним етапом виходу особистості із складних життєвих обставин та опанування нею суб'єктної позиції що до власного життя. Проте питання побудови перспектив людей, що опинились в ситуації АТО є недостатньо вивченим.

Мета нашого дослідження: дослідити вплив важкої життєвої ситуації на формування особистістю перспективи власного життя.

\section{Виклад основного матеріалу дослі-} дження. Для проведення дослідження нами були виділені наступні групи респондентів за критерієм невизначеності ситуації: військові АТО (представники ВСУ та служба за контрактом), що безпосередньо беруть участь у військових діях, особи, що мають статус ВПО, 
мешканці прикордонних із зоною АТО територій. В якості контрольної групи у нашому дослідженні виступили мешканці стабільних територій. Всього в опитуванні приймало участь 187 осіб віком від 19 до 56 років, тобто респонденти дорослого віку. Дослідження проводилось за допомогою модифікованої методики «Каузометрія» С. І. Головаха та О. О. Кронік.

Досліджуваним пропонувалось на лінії, яка відображає їх життєвий шлях, визначити 5 подій, які на думку респондентів увійшли до їх життєвого досвіду та 5 передбачуваних чи можливих подій їх майбутнього. Було проведено якісний та кількісний аналіз компонентів перспективи особистості, що знаходиться в умовах АТО.

Згідно із проведеним нами дослідженням життєвого досвіду особистості, що знаходиться у зоні АТО, нами було виділено наступні компоненти життєвого досвіду особистос- (прагматично-практичний компонент), розкриття власних смислів та цінностей, закладених в ситуації (смисловий компонент)[8].

Ці компоненти відповідають наступним характеристикам життєвої перспективи особистості: диференційованість/ недиференційованість - змістовний компонент, оптимістичність/песимістичність - емоційно-переживальний компонент, реалістичність/нереалістичність - прагматичнопрактичний компонент, нормативність/ особистісність - смисловий компонент.

Наше дослідження будувалось на аналізі життєвої перспективи особистості, що знаходиться в умовам АТО згідно із цими характеристиками та компонентами.

При дослідженні змістовного компонента перспективи ми проаналізували наявність та відсутність опису подій майбутнього досліджуваними. Нами були отримані наступні результати, представлені в таблиці 1.

Таблиия 1

\section{Опис змісту перспективи власного життя за результатами Каузометрії для респон-} дентів

\begin{tabular}{|l|l|l|}
\hline Групи & Перспектива власного життя \\
\hline & Наявність & Відсутність \\
\hline Військові АТО & $73,1 \%$ & $26,9 \%$ \\
\hline ВПО & $96 \%$ & $4 \%$ \\
\hline Мешканці прикордонної зони АТО & $93,62 \%$ & $6,38 \%$ \\
\hline Мешканці стабільних регіонів & $99 \%$ & $1 \%$ \\
\hline
\end{tabular}

ті: цілісний опис ситуації (змістовний компонент), опис власних переживань та емоцій що до ситуації (емоційно-переживальний компонент), структура власної дії в ситуації
Найбільш важким завдання описати події власної перспективи виявилось для представників групи військові АТО, 26,9\% представників цієї групи не змогли описати влас- 
не майбутнє. Мешканці прикордонних із зоною АТО територій та ВПО не змогли описати події власної перспективи у 6,38\% та 4\% випадків відповідно. В той час коли серед представників контрольної групи тільки 1\% респондентів не надали описання власної перспективи. Це може бути пов'язано із тим, що знаходження особистості у ситуації невизначеності ускладнює формування нею диференційованої перспективи власного життя.

За результатами якісного аналізу подій, які увійшли до особистісного досвіду індивіда та складають перспективу його майбутнього, ми склали відповідну таблицю.
АТО стала більш актуальною. Для представників групи мешканці прикордонних із зоною ATO територій сфера майбутніх придбань майже втратила своє значення. Для представників груп ВПО та мешканці прикордонних територій питання переїзду на інше місце проживання $\epsilon$ найбільш актуальним. Таким чином можна зазначити, що ситуація невизначеності, в якій перебувають респонденти впливає на вибір ними сфер, що входять до їх перспективи майбутнього.

Емоційний компонент перспективи особистості ми дослідили за допомогою колірного тесту відносин (КТВ) А. Еткінда, методиТаблиия 2.

Сфери, які обираються для опису перспектив особистість, що знаходиться в умовах АТО

\begin{tabular}{|l|l|l|l|l|}
\hline Сфери & Військові АТО & ВПО & $\begin{array}{l}\text { Ме- } \\
\text { шк.прикорд.тер. }\end{array}$ & $\begin{array}{l}\text { Ме- } \\
\text { шк.стаб.тер. }\end{array}$ \\
\hline Діти & $51,56 \%$ & $63,63 \%$ & $76,1 \%$ & $50,01 \%$ \\
\hline Сім'я & $51,85 \%$ & $63,36 \%$ & $58,33 \%$ & $44,44 \%$ \\
\hline Работа, кар'єра, бізнес & $37,04 \%$ & $44,94 \%$ & $65,27 \%$ & $79,63 \%$ \\
\hline Покупки & $22,22 \%$ & $19,56 \%$ & $6,94 \%$ & $49,74 \%$ \\
\hline Подорожі & $11,11 \%$ & $31,82 \%$ & $37,5 \%$ & $44,44 \%$ \\
\hline Навчання & $14,81 \%$ & $13,64 \%$ & $12,5 \%$ & $22,22 \%$ \\
\hline Переїзд & $7,41 \%$ & $27,27 \%$ & $27,78 \%$ & $12,96 \%$ \\
\hline
\end{tabular}

Для всіх представників груп, пов'язаних із АТО при формуванні перспективи особистості сфера роботи та бізнеса стає менш значущою, особливо це стосується групи військових АТО. Можливо це пов'язано із тим, що на момент проведення опитування для представників цієї групи служба в армії стала професійною діяльністю без залежності від виду служби. При цьому сфера сім’ї та дітей для представників всіх груп, пов'язаних із ка «Вибір кольору» М. Люшера.

В нашому дослідженні респондентам було запропоновано із набора колірних стимулів кольорового тесту М. Люшера обрати до кожної події майбутнього один із кольорів, 3 яким ця подія асоціюється для них.

За результатами дослідження вибору кольорів складена Таблиця 3.

Таким чином кольори основного спектра для емоційної оцінки власного майбутнього 
Вибір кольорів 3 якими асоціюється у респондентів власне майбутнс

\begin{tabular}{|l|l|l|l|l|l|l|l|l|}
\hline & Жовтий & Синій & $\begin{array}{l}\text { Зеле- } \\
\text { ний }\end{array}$ & $\begin{array}{l}\text { Черво- } \\
\text { ний }\end{array}$ & $\begin{array}{l}\text { Фіоле- } \\
\text { товий }\end{array}$ & Сірий & $\begin{array}{l}\text { Корич- } \\
\text { нввий }\end{array}$ & Чорний \\
\hline $\begin{array}{l}\text { Військові } \\
\text { АТО }\end{array}$ & $17,18 \%$ & $21,87 \%$ & $15,63 \%$ & $29,69 \%$ & $9,38 \%$ & $3,13 \%$ & $1,56 \%$ & $1,56 \%$ \\
\hline ВПО & $16,07 \%$ & $17,86 \%$ & $21,43 \%$ & $33,93 \%$ & $3,57 \%$ & $1,78 \%$ & $3,57 \%$ & $1,78 \%$ \\
\hline $\begin{array}{l}\text { Мешканці пр. } \\
\text { тер. }\end{array}$ & $20 \%$ & $17,5 \%$ & $25 \% \%$ & $20,83 \%$ & $8,33 \%$ & $6,68 \%$ & $0,83 \%$ & $0,83 \%$ \\
\hline $\begin{array}{l}\text { Мешканці } \\
\text { стаб.тер. }\end{array}$ & $23,4 \%$ & $16,96 \%$ & $17,01 \%$ & $19,09 \%$ & $5,53 \%$ & $9,5 \%$ & $4,32 \%$ & $4,52 \%$ \\
\hline
\end{tabular}

обирають 84,37\% представників групи військові АТО, 89,29\% - ВПО, 83,33\% - мешканців прикордонних із зоною АТО територій та $76,46 \%$ групи стабільних регіонів. Можливо це пов'язано із ефектом «відсроченого благополуччя», описаного в науковій літературі [2], бо більшість респондентів, пов'язаних з АТО оцінюють своє теперішнє негативно. Тобто оптимістичність майбутньої перспективи не залежить безпосередньо від ступеню ситуації невизначеності, в якій знаходиться особистість.

На наступному етапі нашого дослідження ми проводили діагностику смислового компоненту перспективи особистості, що знаходиться в умовах АТО. Для цього нами був проведений аналіз описаних респондентами значущих подій майбутнього за наступними ознаками: опис події по нормативному принципу (соціальній ознаці) чи по особистісному; особистісні смисли події виділяються чи не виділяються. При цьому подіями, які виділяться по нормативному принципу ми вважаємо ті події, які розкривають участь чи входження людини до основних соціальних інститутів, таких як школа, ВУЗ, початок трудової діяльності, створення сім'ї, вихід на пенсію тобто такі, що відповідають нормативним представленням про життєвий шлях особистості. Події, які виділялися респондентами по особистісній ознаці ми вважаємо події, які не пов'язані із соціальними інститутами та мають для людини індивідуальне значення. Описання особистісних смислів події може бути

Табличя 4.

Підстави для вибору подій перспективи та вираженість смислу для респондентів

\begin{tabular}{|l|l|l|l|l|l|}
\hline \multirow{2}{*}{ Показники } & Признаки & Військові АТО & ВПО & $\begin{array}{l}\text { Мешк.прикор. } \\
\text { тер }\end{array}$ & Мешк.стаб.тер \\
\hline \multirow{2}{*}{ подія } & Норм.принцип & $57,69 \%$ & $60,00 \%$ & $53,97 \%$ & $46,43 \%$ \\
\cline { 2 - 6 } & Особ.принцип & $23,08 \%$ & $40,00 \%$ & $42,86 \%$ & $46,43 \%$ \\
\hline \multirow{2}{*}{ смисл } & Виражений & $34,62 \%$ & $38,00 \%$ & $41,27 \%$ & $28,57 \%$ \\
\cline { 2 - 6 } & Не виражений & $46,15 \%$ & $58,00 \%$ & $55,56 \%$ & $64,29 \%$ \\
\hline
\end{tabular}


виражене респондентами в описі цих подій, чи не виражене.

Результат аналізу анкет за цими показниками наведені у Таблиці 4.

Проаналізувавши дану таблицю можна зробити висновки про те, що описуючи власну життєву перспективу більшість респондентів пов'язаних із АТО обирають події по нормативному принципу, у той час, як мешканці стабільних регіонів України частіше обирають ці події виходячи із особистісного принципу. Проте військові та мешканці сірих зон частіше описують власні смисли, що стали ключовими при виборі подій можливого чи плануємого майбутнього. Це може бути пов'язано із тим, що для представників груп, що пов'язані 3 ATO на перший план виходить смисловий компонент досвіду та перспективи особистосTi. [8]

Дослідження прагматично-практичного компонента перспективи особистості було проведено нами на підставі рефлексивного аналізу респондентами власних дій, що призвели чи можуть призвести до настання обраної події. За результатами дослідження була складена таблиця 5.

Таким чином можна зробити висновки, що дії які необхідно здійснити для настання тієї чи іншої події $є$ не рефлексивними для більшості респондентів. Найменше розуміння що до власних дій, що можуть призвести до події, яка обирається респондентами як власне можливе майбутнє продемонстрували представники групи Військові АТО та мешканці прикордонних із зоною АТО територій. Це може бути пов'язано із тим, що для військових, які на момент проведення дослідження знаходились безпосередньо у зоні бойових дій завдання побудови власного майбутнього не $\epsilon$ актуальним. Проте це питання постане перед представниками цієї групи після демобілізації. В той час як для мешканців так званих «сірих» зон ситуація теперішнього є найменш визначеною, що негативно відображається на суб'єктній позиції представників цієї групи. При цьому представники групи ВПО продемонстрували збільшення здатності до рефлексивного аналізу власного майбутнього у порівнянні із контрольною групою. Це може бути пов'язано із тим, що перед ними питання по-

\section{Таблиия 5.}

Дослідження прагматично-практичного компонента досвіду та перспективи особистості для респондентів

\begin{tabular}{|l|l|l|l|l|l|}
\hline & $\begin{array}{l}\text { Загальний } \\
\text { масив }\end{array}$ & $\begin{array}{l}\text { Військові } \\
\text { АТО }\end{array}$ & ВПО & $\begin{array}{l}\text { Ме- } \\
\text { шк.прик.тер. }\end{array}$ & Мешк.ст.тер. \\
\hline Дії рефлекс. & $22,38 \%$ & $17,39 \%$ & $28,45 \%$ & $19,14 \%$ & $24,56 \%$ \\
\hline Дії не рефлекс. & $77,62 \%$ & $82,61 \%$ & $71,55 \%$ & $80,86 \%$ & $75,44 \%$ \\
\hline
\end{tabular}


будови майбутнього на момент проведення опитування постало найгостріше.

За результатами проведеного дослідження ми можемо зазначити, що для побудови диференційованої, оптимістичної, реалістичної та особистісної перспективи особистості необхідно врахування всіх виділених компонентів. Так смисловий компонент стає основою для формування власного «Хочу» та переходить у мотивацію індивіда. Прагматичнопрактичний компонент стає основою для формування власної ресурсності особистості, тобто формування власного «Можу». Емоційнопереживальний компонент стає основою для формування власного «Буду», тобто формує емоційну готовність індивіда до майбутнього. Змістовний компонент відповідає за наявність перспективи особистості, та відповідає на запитання про те що саме може увійти до ії бажаного чи очікуваного майбутнього.

За результатами нашого дослідження для кожної з обраних груп ми отримали наступну результати: Для представників групи Військові АТО перспектива майбутнього є погано диференційованою (73,1\% респондентів описують події власного майбутнього), найбільш представленими сферами, можливого чи очікуваного майбутнього є сім'я та діти; 84,4\% представників цієї групи позитивно оцінюють власну перспективу; події власної перспективи представники цієї групи обирають здебільшого за нормативною ознакою, проте смисли $\epsilon$ доволі вираженими ( $34,6 \%)$; власні дії щодо настання тієї чи іншої події очікуваного майбутнього при цьому погано рефлексуються (82,6\%). Для представників групи ВПО перспектива є диференційованою (96\%), найбільш представлені такі сфери, як діти і сім'я; оцінка власних перспектив при цьому є найбільш позитивною серед усіх груп (89\%); події обираються за нормативною ознакою та смисл виражений у 38\% респондентів; власні дії що до настання подій прогнозуємого майбутнього рефлексуються 28,5\%, що є найвищім результатом серед усіх груп. Для представників групи Мешканці прикордонних територій перспектива є доволі диференційованою $(93,6 \%)$, за сферами найбільше представлені: діти та робота, кар'єра; емоційна оцінка власних перспектив є доволі позитивною (83\%);події обираються майже з однаковою частотою за особистісною (43\%) та нормативною (54\%) ознаками, смисли виражені найбільше серед усіх груп (41\%); при цьому власні дії рефлексуються лише 19\% респондентів цієї групи. Для представників групи Мешканці стабільних регіонів перспектива власного майбутнього $€$ найбільш диференційованою серед усіх груп (99\%). Найбільша різниця виявлена що до сфер подій можливого майбутнього, слід зазначити що для представників цієї групи різноманітність сфер представлена більш широко, найчастіше обираються такі сфери: робота, кар'єра, бізнес (79\%); діти (50\%); покупки (49,7\%); подорожі та сім'я (по 44\%). Емоційна оцінка власних перспектив при цьому є най- 
нижчою серед усіх груп, позитивно оцінюють власні перспективи 76,5\% респондентів. Події обираються з однаковою частотою за нормативним та особистісним принципами, при цьому смисли виражаються лише 28,5\% респондентів цієї групи, що є найнижчими показниками серед усіх груп. Рефлексивність дій що до настання обираємих подій серед інших груп є доволі висока $(25,5 \%)$.

Висновки. Для представників групи Військові АТО власна перспектива є погано диференційованою, оптимістичною, наповненою здебільшого нормативними смислами, які осознаються, та не рефлексивною. Для представників групи ВПО перспектива є диференційованою оптимістичною, події обираються за нормативною ознакою, однак смисл подій та рефлексія власних дій що до настання цих подій $є$ найвищими серед усіх груп, включаючи мешканців стабільних регіонів. Для представників групи Мешканці прикордонних із зоною АТО територій перспектива $є$ диференційованою, позитивною, осмисленою проте мало рефлексивною. Перспектива для мешканців стабільних регіонів $\epsilon$ диференційованою, 3 поміркованою емоційною оцінкою, смисли є мало вираженими, проте рефлексивність що до власних дій $є$ вище середньої. Таким чином можна зазначити, що складна життєва ситуація теперішнього особистості впливає на те, яку саме перспективу власного життя вона формує.

Отже перед психологами, які працю- ють із особистістю, що знаходиться в умовах АТО постає завдання здійснення психологічної допомоги не тільки для подолання наслідків минулих травмуючих подій, а й побудови особистістю власної усвідомленої та збалансованої перспективи майбутнього. Компонентами якої стають змістовний, смисловий, емоційно-переживальний та прагматичнопрактичний компоненти у своїй єдності. При деривації будь якого 3 цих компонентів у структурі життєвої перспективи особистості втрачається можливість побудувати власну особистісну, реалістичну, оптимістичну, диференційовану та узгоджену перспективу.

Перспектива подальшого дослідження полягає у створенні програми психологічної допомоги для побудови представниками виділених груп узгодженої перспективи власного майбутнього.

\section{Перелік використаних джерел:}

1. Головаха Е.И. Психологическое время личности / Е. И. Головаха, А. А. Кроник. - 2-е изд., испр. и дополн. М. : Смысл, 2008. -267 с.

2.Неяскина Ю.Ю. Взаимосвязь субъективного качества жизни и временной перспективы личности / Ю.Ю. Неяскина, А.В. Мазурчевич // Вестник КРАУНЦ. Гуманитарные науки. 2014. №1 [Электронный ресурс]. - Режим доступа: https://cyberleninka.ru/article/n/vzaimosvyazsubektivnogo-kachestva-zhizni-i-vremennoy-perspektivylichnosti.

3.Особистість як суб'єкт подолання кризових ситуацій: психологічна теорія і практика : монографія / за ред.С. Д. Максименка, С. Б. Кузікової, В. Л. Зливкова. - Суми :Вид-во СумДПУ імені А. С. Макаренка, 2017. - 540 
c.

4.Психосоціальна підртимка осіб з травмою війни: міжнародний досвід та українські реалії: збірник матеріалів, доповідей Всеукраїнської науково-практичної конференції, м. Маріуполь, 28 лютого 2018 р. - Маріуполь: ДонДУУ, 2018. - 322 с.

5.Сьомкіна I.C. Соціально-педагогічна робота 3 сім`ями вимушених переселенців: стан та перспективи / Сьомкіна I.C. // Збірник наукових праць Хмельницького інституту соціальних технологій Університету «Україна», №1 1/2015 С.102-105.

6.Тімченко О.В. Психологічні особливості «виходу 3 війни» військовослужбовців та працівників служби порятунку / О. В. Тімченко //Психічне здоров'я особистості у кризовому суспільстві / збірник тез III Всеукраїнської науково-практичної конференції (19 жовтня 2018 року) / ред. Н. М. Бамбурак. Львів: ЛьвДУВС, $2018.448 \mathrm{c}$.

7.Хорунжий С.М. Психологічна робота 3 посттравматичними стресовими розладами у військовослужбовців Збройних Сил України / С.М. Хорунжий, I.О. Пішко, Н.С. Лозинська // Методичний посібник. Київ: НДЦ ГП ЗСУ.- 2017.

8.Швалб Ю.М. Факторна модель життєвого досвіду особистості, що знаходиться в умовах АТО / Ю.М. Швалб, О.В. Павленко // Психологія: теорія і практика: збірник наукових праць / ред.кол. : I.О. Корнієнко (гол.ред.). - Мукачево : РВВ МДУ, 2018. - Випуск 2. С. $128-139$.

\section{References (Transliteration):}

1. Golovakha Ye.I. Psikhologicheskoye vremya lichnosti / Ye. I. Golovakha, A. A. Kronik. - 2-ye izd., ispr. i dopoln. - M. : Smysl, 2008. - 267 s.

2.Neyaskina YU.YU. Vzaimosvyaz' sub"yektivnogo kachestva zhizni i vremennoy perspektivy lichnosti / YU.YU. Neyaskina, A.V. Mazurchevich // Vestnik KRAUNTS. Gumanitarnyye nauki. 2014. №1 [Elektronnyy resurs]. - Rezhim dostupa: https://cyberleninka.ru/article/n/ vzaimosvyaz-subektivnogo-kachestva-zhizni-i-vremennoyperspektivy-lichnosti.

3.Osobystist' yak sub"yekt podolannya kryzovykh sytuatsiy: psykholohichna teoriya i praktyka : monohrafiya / za red.S. D. Maksymenka, S. B. Kuzikovoyi, V. L. Zlyvkova. - Sumy :Vyd-vo SumDPU imeni A. S. Makarenka, 2017. $-540 \mathrm{~s}$.

4.Psykhosotsial'na pidrtymka osib $\mathrm{z}$ travmoyu viyny: mizhnarodnyy dosvid ta ukrayins'ki realiyi: zbirnyk materialiv, dopovidey Vseukrayins'koyi naukovo-praktychnoyi konferentsiyi, m. Mariupol', 28 lyutoho 2018 r. - Mariupol': DonDUU, 2018. - $322 \mathrm{~s}$.

5.S'omkina I.S. Sotsial'no-pedahohichna robota $\mathrm{Z}$ sim yamy vymushenykh pereselentsiv: stan ta perspektyvy / S'omkina I.S. // Zbirnyk naukovykh prats' Khmel'nyts'koho instytutu sotsial'nykh tekhnolohiy Universytetu «Ukrayina», №11/2015 S.102-105.

6. Timchenko O.V. Psykholohichni osoblyvosti «vykhodu z viyny» viys'kovosluzhbovtsiv ta pratsivnykiv sluzhby poryatunku / O. V. Timchenko //Psykhichne zdorov'ya osobystosti u kryzovomu suspil'stvi / zbirnyk tez III Vseukrayins'koyi naukovo-praktychnoyi konferentsiyi (19 zhovtnya 2018 roku) / red. N. M. Bamburak. L'viv: L'vDUVS, 2018. $448 \mathrm{~s}$.

7.Khorunzhy S.M. Psykholohichna robota z posttravmatychnymy stresovymy rozladamy $\mathrm{u}$ viys'kovosluzhbovtsiv Zbroynykh Syl Ukrayiny / S.M. Khorunzhyy, I.O. Pishko, N.S. Lozyns'ka // Metodychnyy posibnyk. Kyyiv: NDTS HP ZSU.- 2017.

8.Shvalb YU.M. Faktorna model' zhyttyevoho dosvidu osobystosti, shcho znakhodyt'sya v umovakh ATO / YU.M. Shvalb, O.V. Pavlenko // Psykholohiya: teoriya i praktyka: zbirnyk naukovykh prats' / red.kol. : I.O. Korniyenko (hol.red.). - Mukachevo : RVV MDU, 2018. - Vypusk 2. S. $128-139$. 


\section{Pavlenko Oksana}

Scientific fellow of the laboratory of ecological psychology of H.S. Kostiuk Institute of Psychology of the National Academy of Educational Sciences of Ukraine, Kiev (Ukraine)

\section{LIFE PERSPECTIVE OF PEOPLE WHO ARE IN THE CONDITIONS OF ANTI- TERRORIST OPERATION} (ATO)

\section{ABSTRACT}

The article deals with the peculiarities of the formation of the life perspective of people who are in the conditions of ATO. The main parameters, functions and forms of awareness of personal life perspectives are revealed. The following characteristics and components of the life perspective of the individual are singled out: differentiation / non-differentiation - the content component, optimism / pessimism - the emotional and experiencing component, realism / unrealism - the pragmatic-practical component, normativity / personality - the semantic component. According to these components, the author made the analysis of the structure of the life perspective of the respondents in the ATO zone, in particular ATO fighters, internally displaced people, residents of the "gray" zones and residents of stable territories of Ukraine. The divergences in the presented perspectives of their own lives in the consciousness of these groups of respondents were revealed and analyzed. It was stated that the least differentiated perspective is among the representatives of the military men participating in the ATO. Optimism about their own future was demonstrated by all categories of respondents. The sense of the own perspective is at a fairly high level for all groups of respondents related to ATO, but events are most often selected on a normative basis, as opposed to representatives of the group of stable territories. The reflexivity concerning the actions which are to be taken in order to reach this or that planned or anticipated event was shown by the representatives of IDP group, they surpassed the representatives of the group of stable regions for this indicator. According to the results of the conducted research, we can note that for the construction of a differentiated, optimistic, realistic and personal perspective of the individual, it is necessary to take into account the content of the perspective, its emotional assessment, semantic and pragmatic-practical component. The results of the above research can be used to create a program of psychological assistance to ATO fighters, IDP and residents of the border areas with the zone of ATO (gray zones) to facilitate the construction of their own future perspectives.

Keywords: life perspective of the person, characteristics of life perspective, life experience, planned events, formation of coordinated perspective of one's own life.

(C) Павленко О. В. 


\section{Павленко Оксана Владимировна}

Научный сотрудник лаборатории экологической психологии института психологии имени Г.С. Костюка Национальной академии педагогических наук Украины, г. Киев (Украина)

\section{ЖИЗНЕННЫЕ ПЕРСПЕКТИВЫ ЛИЧНОСТИ, КОТОРАЯ НАХОДИТСЯ В УСЛОВИЯХ АНТИТЕРРОРИСТИЧЕСКОЙ ОПЕРАЦИИ (АТО)}

Аннотация. В статье рассмотрены особенности формирования жизненной перспективы личностью, которая находится в условиях АТО. Раскрыты основные параметры, функции и формы осознания собственных жизненных перспектив личностью. Выделенные следующие характеристики и компоненты жизненной перспективы личности: диференцированность/ не диференцированность содержательный компонент, оптимистичность/песимистичность - емоциональнопереживательный компонент, реалистичность/ нереалистичность практический компонент, нормативность/ личностность - смысловой компонент. Согласно этим компонентам сделан анализ структуры жизненной перспективы респондентов, которые находятся в зоне АТО, в частности бойцов АТО, внутренне перемещенных лиц, жителей «серых» зон и жителей стабильных территорий Украины. Выявлены и проанализированы расхождения в представленности перспективы собственной жизни в сознании этих групп респондентов. Выявлено, что наименее дифференцирована перспектива для представителей группы военные АТО. Оптимистичность по отношению к собственному будущему продемонстрировали все категории респондентов. Осмысленность собственной перспективы находится на достаточно высоком уровне для всех групп респондентов, связанных с АТО, однако события чаще всего выбираются ими по нормативному признаку в отличие от представителей группы жителей стабильных территорий. Рефлексивность по отношению к действиям, которые необходимо осуществить для наступления того или другого планируемого или ожидаемого события продемонстрировали представители группы ВПО, по этому показателю они попередили представителей группы стабильных регионов. По результатам проведенного исследования мы можем отметить, что для построения дифференцированной, оптимистичной, реалистичной и личностной перспективы необходимо учитывание содержание перспективы, ее эмоциональную оценку, смысловую и прагматично-практическую составляющие. Результаты данного исследования могут быть использованы для создания программы психологической помощи бойцам АТО, ВПО и жителям пограничных с зоной АТО территорий (серых зон) для фоссилизации построения ими перспективы собственного будущего.

Ключевые слова: жизненная перспектива личности, характеристики жизненной 
перспективы, жизненный опыт, планируемые события, формирования согласованной перспективы собственной жизни. 